\title{
Potential of Virginia Mallow as an Energy Feedstock
}

\author{
S. W. Banks ${ }^{1} \cdot$ M. Śnieg $^{2}$ - D. J. Nowakowski ${ }^{1}$ (D) M. Stolarski ${ }^{2}$ A. V. Bridgwater ${ }^{1}$
}

Received: 7 March 2020 / Accepted: 20 July 2020 / Published online: 1 August 2020

(c) The Author(s) 2020

\begin{abstract}
This study aims to compare the potential of Virginia mallow to other high yielding perennial grasses and hardwoods by characterising and comparing fast pyrolysis product yields. Feedstocks selected for this study include miscanthus (Miscanthus $x$ giganteus), Virginia mallow (Sida hermaphrodita), willow short rotation coppice (SRC) (Salix viminalis) and oak (Quercus robur). The experimental work was split into two sections: analytical (Py-GC-MS) and laboratory-scale processing using a $300 \mathrm{~g} \mathrm{~h}^{-1}$ continuous bubbling fluidised bed reactor. Pyrolysis-gas chromatography-mass spectrometry (Py-GC-MS) has been used to quantify pyrolysis products from these feedstocks by simulating fast pyrolysis heating rates using a CDS 5200 pyrolyser closed coupled to a PerkinElmer Clarus 680 GC-MS. High bio-oil yields were achieved for Virginia mallow, willow SRC and oak (65.36, 62.55 and $66.43 \mathrm{wt} \%$ respectively), but miscanthus only produced a yield of $53.46 \mathrm{wt} \%$ due to increased feedstock ash content. The water content in the bio-oil is highest from miscanthus (17.64 wt\%) and relatively low in the Virginia mallow and hardwoods willow SRC and oak (12.49, 13.88 and $14.53 \mathrm{wt} \%)$. Similar high yields of bio-oil and low yields of char and non-condensable gas compared to willow SRC make Virginia mallow an attractive feedstock for fast pyrolysis processing.
\end{abstract}

\section{Graphic Abstract}

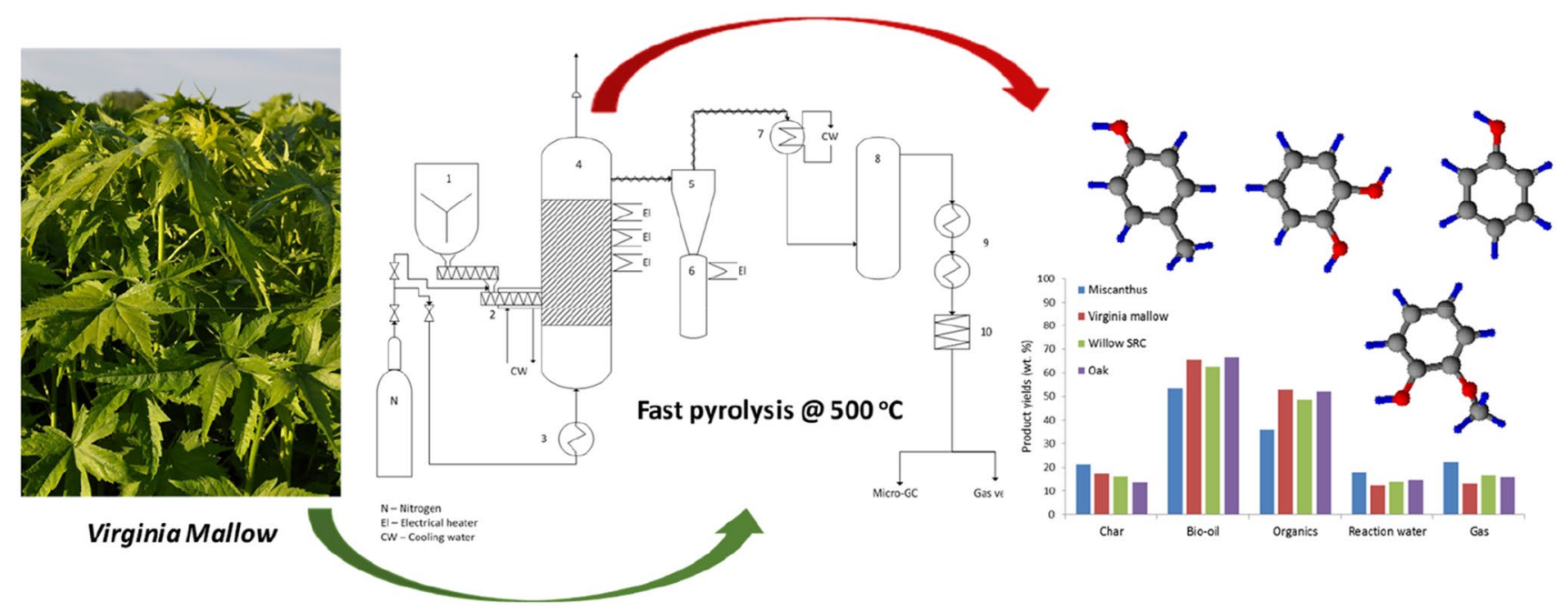

Keywords Virginia mallow $\cdot$ Energy feedstock $\cdot$ TGA $\cdot$ Py-GC-MS $\cdot$ Fast pyrolysis $\cdot$ Bio-oil

D. J. Nowakowski

d.j.nowakowski@aston.ac.uk

1 Energy and Bioproducts Research Institute, Aston University, Birmingham B4 7ET, United Kingdom

2 Faculty of Environmental Management and Agriculture, University of Warmia and Mazury in Olsztyn, 10-724 Olsztyn, Poland

\section{Statement of Novelty}

Virginia mallow is proposed as an alternative to other energy feedstocks used for production of bio-fuels and value added chemicals. Virginia mallow has been sustainably cultivated 
in European trials with comparable harvested yields to other energy grasses. This novel feedstock generates similar homogeneous bio-oil liquid yields compared to the hardwood feedstocks with improved chemical composition when compared to bio-oils produced from similar yielding feedstocks. Therefore, the novelty of this study was highlighting the similar harvesting yields of Virginia mallow to energy grasses whilst producing comparable bio-oil yields and physico-chemical properties to standard woody biomass.

\section{Introduction}

Renewable energy sources from biomass are becoming more critical when considering the reduction of environmental concerns from fossil fuels from carbon dioxide emissions. It has been widely accepted that climate change is occurring due to the combustion of fossil fuels resulting in the accumulation of greenhouse gases in the atmosphere [1,2]. Renewable and alternative energy sources are keys to the solution of a twin problem, energy and climate change but require a high initial investment. One of these approaches is fast pyrolysis which is capable of producing petroleumlike products and higher value chemicals from renewable sources. Fast pyrolysis converts renewable sources by rapid heating in the absence of oxygen and then rapid cooling of the vapours [3]. The products are bio-oil, non-condensable gases and char.

One of these renewable sources is Virginia mallow, which is a tall, distinctive, perennial flowering herb native to North America [4-8]. It is not a short rotation woody crop like willow or perennial grass-like miscanthus, but it is a soft woody herbaceous energy crop, based on its stem structure and chemical content $[9,10]$. Virginia mallow can reach one to three metres in height, and the flowers are made up of five white petals that grow in a clustered formation. Virginia mallow grows naturally in riparian habitats (interface between land and a river or stream) that are flooded in most years. It benefits from a moist environment and is usually found in sunny or partly shaded areas with sandy soil. The species ranges across eastern North America and is considered globally rare (G3).

In the last $10-15$ years, the perennial Virginia mallow has received attention as an energy feedstock. It has been suggested by many authors that cultivating perennial species for energy purposes is superior to cultivated annual species because perennials are less expensive to grow, result in higher production profitability and have higher energy potential $[11,12]$. Virginia mallow has attracted much interest from researchers as it is a fast-growing plant with high potential yields, and it can regrow after multiple cuttings. Depending on soil type and other abiotic and biotic factors, Virginia mallow yields (dry mass) can vary from 9 to 20 t ha $a^{-1}$ DM $[6,7,9,10,13]$ compared to $17-19 \mathrm{t} \mathrm{ha}^{-1} \mathrm{DM}$ from miscanthus and 11-13 $\mathrm{t} \mathrm{ha}^{-1} \mathrm{DM}$ from willow [14]. Although energy crops have a good potential for use as a biomass source, they should be cultivated on land that is less favourable for farming to avoid direct competition with conventional food plants. Virginia mallow does not need high management requirements and may be grown in less fertile soils [15]. It is highly adaptable to different climates and can be grown on the slopes of eroded areas, land which is excluded from agricultural use, on chemically degraded areas, also on dumps and landfills of rubbish. There is currently no data available on the tolerance of Virginia mallow to different soil $\mathrm{pH}$ levels and the effects of liming.

The objective of this study was to compare the potential of Virginia mallow as an energy feedstock to other high yielding perennial grasses and hardwoods by characterising and comparing fast pyrolysis product yields. Feedstocks selected for this study were: miscanthus (Miscanthus $x$ giganteus), Virginia mallow (Sida hermaphrodita), short rotation coppice willow (Salix viminalis) and oak (Quercus robur). The reported products yields are different from other studies, and this is thought to be due to feedstock source, reactor type, experimental set-up and processing capacity. Results from this study will contribute to the existing knowledge of crop pyrolysis products and yields. They will allow for better comparison between different feedstocks and the potential for bio-oil use and upgrading.

\section{Methodology}

\section{Feedstock}

Four feedstock samples were used for this research: miscanthus, SRC willow, Virginia mallow and oak. Miscanthus, SRC willow and Virginia mallow were harvested in March 2015 and plants cultivated in an experimental field set up in the spring of 2011, at the Research Station in Bałdy $\left(53^{\circ}\right.$ $35^{\prime} \mathrm{N}, 20^{\circ} 36^{\prime} \mathrm{E}$ ) belonging to the University of Warmia and Mazury in Olsztyn, Poland. In the years of conducting the experiment, standard agrotechnical measures were carried out, consisting of mechanical control of weeds; pesticides were not used in the experiment; During the field trial, each spring the fields were treated with fertiliser dosages of $\mathrm{N}$ $90 \mathrm{~kg} \mathrm{ha}^{-1}, \mathrm{P}_{2} \mathrm{O}_{5} 30 \mathrm{~kg} \mathrm{ha}^{-1}, \mathrm{~K}_{2} \mathrm{O} 60 \mathrm{~kg} \mathrm{ha}^{-1}$; nitrogen was introduced in the form of ammonium nitrate, phosphorus in the form of monocalcium phosphate and potassium in the form of potassium chloride. Plant harvesting was conducted in 1-year cycles, with biomass collected at the end of March each year. For the research presented in this work, biomass was collected at the end-March 2015, so it was biomass from the annual growth of plants growing on a 4-year-old root. After harvesting the plants, the biomass samples were dried 
at $105{ }^{\circ} \mathrm{C}$ until a constant weight was obtained. The samples were then milled in an analytical mill (SM 200 Retsch mill) using a sieve with $1 \mathrm{~mm}$ mesh.

The feedstock samples were prepared before each set of experiments, by grinding (Retsch Ltd., Germany, HeavyDuty Cutting Mill, Type SM2000) and sieving to a particle size fraction of $0.25-1.00 \mathrm{~mm}$. The following particle size fractions were prepared for analysis: particle size $0.25-1.00 \mathrm{~mm}$ for fast pyrolysis processing, particle size $0.15-0.25 \mathrm{~mm}$ for analytical analyses. A biomass splitter was used to obtain a representative sample for Py-GC-MS characterisation.

\section{Thermogravimetric Analysis (TGA)}

The proximate analysis classifies the feedstock in terms of moisture, volatile matter, fixed carbon and ash. The volatile content consists of gases and vapours released during pyrolysis. Ash is the inorganic residue remaining after combustion of the feedstock. TGA data is equivalent to a standardised proximate analysis. Two TGA tests are required for a complete proximate analysis, one performed in a nitrogen atmosphere the second in an air atmosphere.

To study pyrolysis under dynamic heating for feedstock samples $(5 \pm 0.1 \mathrm{mg})$, a PerkinElmer Pyris 1 thermogravimetric analyser was used. A pyrolysis heating rate of $20{ }^{\circ} \mathrm{C} \mathrm{min}-1$ was used, heating from ambient temperature to $550{ }^{\circ} \mathrm{C}$ in a nitrogen flow of $30 \mathrm{ml} \mathrm{min}{ }^{-1}$ [16]. The ash content for the feedstock was determined using a heating rate of $10{ }^{\circ} \mathrm{C} \mathrm{min}^{-1}$, heating from ambient temperature to $575{ }^{\circ} \mathrm{C}$ with a hold time of $15 \mathrm{~min}$ in an air purge rate of

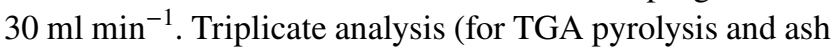
content analysis) was undertaken for each sample.

\section{Ash Content Analysis}

Feedstock ash content was calculated on a moisturefree basis. Before analysis, the feedstock was dried at $60{ }^{\circ} \mathrm{C} \pm 2{ }^{\circ} \mathrm{C}$ for $24 \mathrm{~h}$. Feedstock ash content was calculated using E 1755 ASTM method [17]. Char ash content was calculated on a moisture-free basis. Prior to analysis, the char was dried at $60^{\circ} \mathrm{C} \pm 2{ }^{\circ} \mathrm{C}$ for $24 \mathrm{~h}$. Char ash content was calculated using D 1762 ASTM method [18].

\section{Elemental Analysis and Heating Values}

A Carlo-Erba 1108 elemental analyser EA1108 was used to determine the elemental analysis for carbon, hydrogen, nitrogen and sulphur. Carbon, hydrogen, nitrogen and sulphur content (wt\% on dry basis) were analysed in duplicate, and average values were taken.

The higher heating value (HHV) was calculated using Eq. (1) [19] based on elemental carbon, hydrogen, sulphur, oxygen, nitrogen and ash concentrations. The low heating value (LHV) was obtained using Eq. (2) [19].

$$
\begin{aligned}
& \mathrm{HHV}_{\text {Dry }}\left(\mathrm{MJ} \mathrm{kg.}^{-1}\right)=0.3491 * \mathrm{C}+1.1783 * \mathrm{H} \\
& \quad+0.1005 * \mathrm{~S}-0.1034 * \mathrm{O}-0.015 * \mathrm{~N}-0.0211 * \mathrm{~A}
\end{aligned}
$$

$\mathrm{LHV}_{\text {Dry }}=\mathrm{HHV}_{\text {Dry }}-2.442 * 8.936 * \mathrm{H} / 100$

The higher and lower heating values of the bio-oils, on a wet basis (as-received), were calculated using the following equations.

$\mathrm{HHV}_{\mathrm{a} . \mathrm{r}}(\mathrm{MJ} / \mathrm{Kg}): \mathrm{HHV}_{\text {Dry }} *\left(1-\mathrm{H}_{2} \mathrm{O} / 100\right)$

$\mathrm{LHV}_{\text {a.r }}(\mathrm{MJ} / \mathrm{Kg}): \operatorname{LHV}_{\text {Dry }} *\left(1-\mathrm{H}_{2} \mathrm{O} / 100\right)-2.442 *\left(\mathrm{H}_{2} \mathrm{O} / 100\right)$

where $\mathrm{H}_{2} \mathrm{O}$ in wt $\%$

\section{Pyrolysis-Gas Chromatography-Mass Spectrometry (Py-GC-MS)}

Feedstock samples ( $3 \mathrm{mg}$ ) were pyrolysed using a CDS 5200 pyrolyser close-coupled to a PerkinElmer Clarus 680 gas chromatograph (GC) and Clarus 600S mass spectrometer (MS), to a pyrolysis temperature of $550{ }^{\circ} \mathrm{C}$ (held for $15.0 \mathrm{~s}$ at $550{ }^{\circ} \mathrm{C}$ ) at a heating rate of $20^{\circ} \mathrm{C} \mathrm{ms}^{-1}$. The separation was carried out using a PerkinElmer Elite-1701 column (cross-bond: $14 \%$ cyanopropylphenyl and $85 \%$ dimethyl polysiloxane; $30 \mathrm{~m}, 0.25 \mathrm{~mm}$ i.d., $0.25 \mathrm{~mm} \mathrm{df}$ ). The GC oven was held at $45^{\circ} \mathrm{C}$ for $5 \mathrm{~min}$, then heated at $5{ }^{\circ} \mathrm{C} \mathrm{min}{ }^{-1}$ to $250^{\circ} \mathrm{C}$ and held at this temperature for $5 \mathrm{~min}$. Proposed assignments $(\mathrm{m} / \mathrm{z}=45-300)$ were made from mass spectra detection using the NIST 2011 MS library and from assignments in the literature [20-22]. Peaks were only identified if their relative abundance was above a $20 \%$ threshold.

\section{Fast Pyrolysis Processing}

The fast pyrolysis experiments were carried out in a $300 \mathrm{~g} \mathrm{~h}^{-1}$ continuous bubbling fluidised bed reactor (\#4). A flow sheet of the $300 \mathrm{~g} \mathrm{~h}^{-1}$ fast pyrolysis rig set-up is shown in Fig. 1. The fast pyrolysis processing parameters are summarised in Table 1. The rig is composed of three sections: the feeding system, the fast pyrolysis reactor, and product collection. The feeding system consists of an air-tight hopper (\#1) with a nitrogen purge with speed regulated twin metering screws to supply up to $300 \mathrm{~g} \mathrm{~h}^{-1}$ of feedstock to the high-speed feed screw (\#2) which is water-cooled at the feed point to minimise pre-pyrolysis. Low biomass moisture content is desirable as it helps to reduce the risk of prepyrolysis within the feed screw as the heat is used to evaporate the water, therefore, reducing the possibility of pyrolysis 


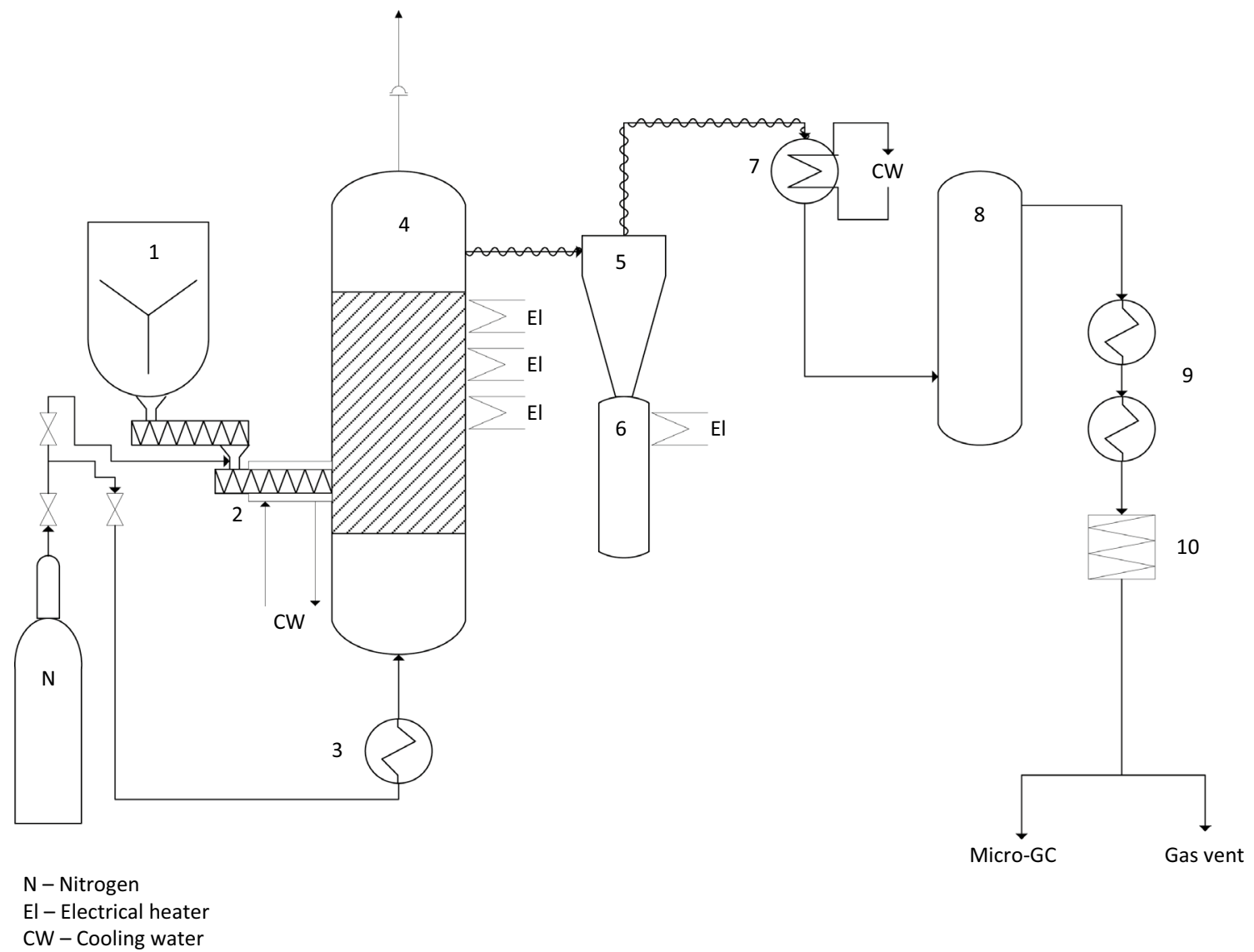

Fig. $1300 \mathrm{~g} \mathrm{~h}^{-1}$ fast pyrolysis rig set-up. 1-feed hopper, 2-fast screw, 3-nitrogen preheater, 4-bubbling fluidised bed reactor, 5-cyclone, 6-char pot, 7—water cooled condenser, 8—electrostatic precipitator, 9—dry ice/acetone condenser, 10—cotton wool filter

Table 1 Fast pyrolysis processing parameters

\begin{tabular}{lllll}
\hline Parameter & Miscanthus & Virginia mallow & SRC willow & Oak \\
\hline Pyrolysis temperature $\left({ }^{\circ} \mathrm{C}\right)$ & 500 & 500 & 500 & 500 \\
Run time $(\mathrm{min})$ & 30 & 30 & 30 & 30 \\
Biomass moisture content $(\%)_{\text {Biomass used }}^{\text {w.b. }}(\mathrm{g})$ & 7.02 & 7.92 & 8.25 & 11.60 \\
Hot vapour residence time $(\mathrm{s})$ & 203.60 & 178.40 & 214.00 & 181.03 \\
\hline
\end{tabular}

w.b. wet basis

taking place. The biomass fraction size has to be between 0.25 and $1.00 \mathrm{~mm}$, as blockages in the hopper or feed screw can occur with smaller or larger particle sizes. The main aim is to bring the biomass particles to the chosen pyrolysis temperature and minimise exposure to lower temperatures which favours the formation of char [3], this can be achieved by using smaller particle sizes ideally below $1.00 \mathrm{~mm}$.

The biomass was fed into the lower part of the fluid bed reactor, $4.10 \mathrm{~cm}$ above the distributor plate. The distributor plate is a porous Inconel plate, which has an average pore size of $0.1 \mathrm{~mm}$, at the bottom of the reactor that disperses the fluidising gas and supports the reactor fluid bed material.
The fluidised bed reactor is made from stainless steel (\#4) and has an internal diameter of $40 \mathrm{~mm}$ and a height of $335 \mathrm{~mm}$. The reactor bed material is $300 \mathrm{~g}$ of sieved quartz sand with a particle size between 500 and $600 \mu \mathrm{m}$. Silica sand was chosen as it is a very efficient heat transfer material due to its high solid density; it is also robust, thermally stable and cheap. Being thermally stable is essential as the silica sand is burnt off after each experiment to remove char.

The reactor was fluidised with three times the minimum fluidising velocity $\left(8.4 \mathrm{dm}^{3} \mathrm{~min}^{-1}\right.$ at $\left.600{ }^{\circ} \mathrm{C}\right)$ of preheated nitrogen used on a single pass basis. A single-pass basis was used so that the gas stream (nitrogen and product gas) can be 
analysed every $150 \mathrm{~s}$; therefore, the product gas composition can be studied at any point during a fast pyrolysis experiment. $251 \mathrm{~min}^{-1}$ (atmospheric test pressure-ATP) of nitrogen resulted in fluidisation of the bed material and proper char particle entrainment with no entrained bed material. The nitrogen was preheated (\#3 in Fig. 1) electrically using a Watlow Starflow circulation preheater (power of $800 \mathrm{~W}$ ) up to $650{ }^{\circ} \mathrm{C}$ prior to the fluid bed reactor. The nitrogen is preheated so that it reduces the load on the reactor heaters and ensures the reactor bed temperature is stable. Fast pyrolysis experiments were carried out to achieve an average pyrolysis temperature of $500 \pm 5^{\circ} \mathrm{C}$; this is a temperature measured directly in the centre of the reactor zone. The reactor is heated using two Watlow ceramic knuckle band heaters, one of $800 \mathrm{~W}$ and the other of $500 \mathrm{~W}$. The temperature of these knuckle band heaters is set higher than the desired pyrolysis reaction temperature to account for heat losses due to the heaters being wrapped around the outside of the reactor. There is approximately a $100{ }^{\circ} \mathrm{C}$ difference between the internal reactor temperature and the knuckle band heater temperature. The temperature of the freeboard is monitored with a single K-type thermocouple; the temperature must be above $400{ }^{\circ} \mathrm{C}$ for any experiments to be able to begin. The residence time of the vapours in the reactor and associated hot pipework and cyclones was calculated to be below $1.1 \mathrm{~s}$. The hot vapour residence time in the reactor and associated hot pipework and cyclones is directly dependent on the fluidisation gas flow rate.

As the vapour and gas stream leaves the reactor, it passes through a single heated cyclone (\#5 in Fig. 1) where the char is separated. The cyclone and pipework are all trace heated to at least $425^{\circ} \mathrm{C}$ to minimise tar condensation leading to blockages and not above $460{ }^{\circ} \mathrm{C}$ to minimise thermal cracking. Following the cyclone, the vapours pass through a water-cooled condenser ( $\# 7$ in Fig. 1) at $5-10{ }^{\circ} \mathrm{C}$. The water is provided via a Huber Minichiller. The aerosols are coalesced in an electrostatic precipitator (\#8 in Fig. 1), working at $10 \mathrm{kV}$ and $0.2 \mathrm{~mA}$. The electrostatic precipitator consists of two electrodes, a central wire cathode and an outer cylindrical anode. The central cathode charges the aerosols so that they migrate to the outer cylindrical anode. The condensed bio-oil is periodically run-off from the condenser and electrostatic precipitator and collected in a round bottom flask. Following the electrostatic precipitator, the gas passes through two dry ice/acetone condensers (\#9 in Fig. 1) in series at $-70{ }^{\circ} \mathrm{C}$ and finally a cotton wool filter (\#10). The liquid collected from the dry ice/acetone condensers is referred to as the secondary condensate. An on-line Varian CP 4900 Micro-GC, micro gas chromatograph with a thermal conductivity detector (TCD) and two columns (Varian CP-5A mol sieve and CP-PortaPLOT), was used for interval analysis (every $150 \mathrm{~s}$ ) of the non-condensable gases for each fast pyrolysis run. Any excess gas was vented to the fume hoods.

\section{Bio-oil Characterisation}

\section{Gas Chromatography-Mass Spectrometry (GC-MS) Analysis of Fast Pyrolysis Liquids (Bio-oils)}

The chemical composition of fast pyrolysis liquids was analysed using a Varian GC-450 chromatograph and MS-220 mass spectrometer. Bio-oil samples were mixed with GC grade acetone at a ratio of $1: 4\left(\mathrm{v} \mathrm{v}^{-1}\right)$ to create the GC sample. For each analysis, $2 \mu \mathrm{l}$ of GC sample was injected onto the GC column; helium was used as the carrier gas. To separate the bio-oil components, a Varian factorFour column was used ( $30 \mathrm{~m}, 0.25 \mathrm{~mm}$ id., $0.25 \mu \mathrm{m} \mathrm{df})$. The injection port was kept at $275^{\circ} \mathrm{C}$, and a $1: 75$ split ratio was used. The GC oven was held at $50{ }^{\circ} \mathrm{C}$ for $3 \mathrm{~min}$, then heated at $5{ }^{\circ} \mathrm{Cmin}^{-1}$ to $250^{\circ} \mathrm{C}$ and held at this temperature for $8 \mathrm{~min}$. Proposed peak assignments $(\mathrm{m} / \mathrm{z}=45-300)$ were made from mass spectra detection using the NIST05 MS library and from assignments in the literature $[20,21]$.

\section{Water Content}

Volumetric Karl-Fischer (KF) titration was used to determine the water content of all the fast pyrolysis liquid products. A Mettler Toledo V20 KF titrator with Hydranal (R) $\mathrm{K}$ as a working medium and Hydranal (R) Composite $5 \mathrm{~K}$ as a titrant. All analyses were performed in triplicate with the water content being calculated automatically by the KF instrument, based on the weight of the bio-oil sample injected. Prior to analysis, the KF instrument was calibrated with HPLC grade water.

\section{$\mathrm{pH}$ Analysis}

A Sartorius PB-11 pH meter was used to measure the acidity of the bio-oils. Prior to each measurement, the $\mathrm{pH}$ meter was calibrated with $\mathrm{pH}$ buffers (pH 2, 4, 7 and 10) which were provided by Sartorius. Calibrations were repeated for each sample to ensure that exact readings were recorded, and the probe was cleaned between sample analyses to ensure no cross-contamination occurred.

\section{Results and Discussion}

\section{Fast Pyrolysis Feedstock Characterisation}

Comparisons of the ultimate and proximate analyses, as well as the higher and lower heating values of the feedstocks investigated, are shown in Table 2. From the ultimate 
Table 2 Elemental analysis of fast pyrolysis feedstocks

\begin{tabular}{|c|c|c|c|c|}
\hline Analysis & Miscanthus & Virginia mallow & SRC willow & Oak \\
\hline \multicolumn{5}{|l|}{ Ultimate analysis $\left(\%^{(\mathrm{d} . \mathrm{b} .)}\right)$} \\
\hline $\mathrm{C}$ & 47.02 & 48.40 & 48.63 & 49.77 \\
\hline $\mathrm{H}$ & 5.54 & 5.91 & 5.78 & 5.88 \\
\hline $\mathrm{N}$ & 0.47 & 0.42 & 0.77 & 0.31 \\
\hline S & $\mathrm{n} / \mathrm{d}$ & $\mathrm{n} / \mathrm{d}$ & $\mathrm{n} / \mathrm{d}$ & $\mathrm{n} / \mathrm{d}$ \\
\hline $\mathrm{O}^{\mathrm{a}}$ & 46.97 & 45.27 & 44.82 & 44.04 \\
\hline \multicolumn{5}{|l|}{ Proximate analysis $(\%)$} \\
\hline Moisture & 5.62 & 6.41 & 5.91 & 5.72 \\
\hline Volatile matter ${ }^{\text {d.b }}$ & 88.43 & 79.74 & 79.48 & 79.59 \\
\hline Fixed carbon ${ }^{\text {d.b }}$ & 7.89 & 18.15 & 18.73 & 19.84 \\
\hline $\operatorname{Ash}^{\text {d.b }}$ & 3.68 & 2.11 & 1.79 & 0.57 \\
\hline ASTM ash content $(\%)$ & 2.79 & 2.32 & 1.20 & 0.23 \\
\hline \multicolumn{5}{|l|}{ Heating value $\left(\mathrm{MJ} \mathrm{kg}^{-1}\right)$} \\
\hline HHV & 18.00 & 19.13 & 19.10 & 19.73 \\
\hline LHV & 16.79 & 17.84 & 17.84 & 18.45 \\
\hline "H:C" atomic ratio & 0.12 & 0.12 & 0.12 & 0.12 \\
\hline "O:C" atomic ratio & 1.00 & 0.94 & 0.92 & 0.88 \\
\hline
\end{tabular}

analysis, the woody feedstocks were seen to have a higher content of carbon and lower oxygen. As a result, the calculated higher and lower heating values were found to be higher for the woody feedstocks. However, only Virginia mallow had a slightly lower carbon content which resulted in a lower higher and lower heating values compared to the woody feedstocks. Results from the proximate analysis show that higher amounts of volatile matter are obtained from miscanthus (88.43 wt\%) with similar amounts of volatiles being achieved for the other three feedstocks (79.48-79.74 $\mathrm{wt} \%)$. ASTM ash content values for miscanthus (2.79 wt \%) and Virginia mallow (2.32 wt $\%$ ) are highest, and lowest for the hardwoods, SRC willow (1.20 wt $\%$ ) and oak (0.23 wt $\%)$.

\section{Thermogravimetric Analysis (TGA)}

The differential thermogravimetric pyrolysis and combustion profiles can be found in Figs. 2 and 3, respectively. The differential thermogravimetric profile (DTG) reports the percentage weight loss per minute as a function of temperature. The DTG profile can be correlated to the feedstock composition [23]. With regards to Figs. 2 and 3, the DTG profile is reflective of the cellulose, hemicellulose, lignin and inorganic content. From the DTG pyrolysis profile, shown in Fig. 2, it can be seen that the pyrolytic decomposition of all biomass samples started at about $175^{\circ} \mathrm{C}$, followed by a significant loss of mass in the temperature range between 250 and $425{ }^{\circ} \mathrm{C}$ during which volatile matter was released and essentially completed by $550{ }^{\circ} \mathrm{C}$, with the formation of char and evolution of secondary gases. The maximum rate of thermal degradation occurs between 341 and $380{ }^{\circ} \mathrm{C}$ for all feedstocks. The first sign of pyrolytic decomposition is attributed to the decomposition of hemicellulose and the initial degradation of cellulose, while the second main peak is due to the final degradation of cellulose and the degradation of lignin [24-26]. Hardwoods are found to have lower maximum thermal decompositions which occur at higher temperatures. This is related to the higher lignin content, which makes up a significant part of the overall structure of hardwoods. Miscanthus has a maximum decomposition rate at the lowest temperature when compared to the other feedstocks.

The DTG combustion profiles shown in Fig. 3 show two distinct decomposition regions. The first decomposition region is representative of the initial volatile combustion and occurs below $375^{\circ} \mathrm{C}$. The temperature of the maximum rate of decomposition is seen to be highest for Virginia mallow and lowest for miscanthus. An increased inorganic content can be assumed for miscanthus, as it has the highest ash content (Table 2), which may be the reason for the difference seen between feedstocks. The second decomposition region is representative of the char burnout and occurs after $375^{\circ} \mathrm{C}$. The first region of decomposition is associated with the combustion of cellulose and hemicellulose, the second region with the combustion of lignin [27, 28]. The combustion of lignin occurs in the second region because it is more aromatic than cellulose and hemicellulose and therefore requires more energy to break the bonds. 
Fig. 2 Differential thermogravimetric pyrolysis profiles

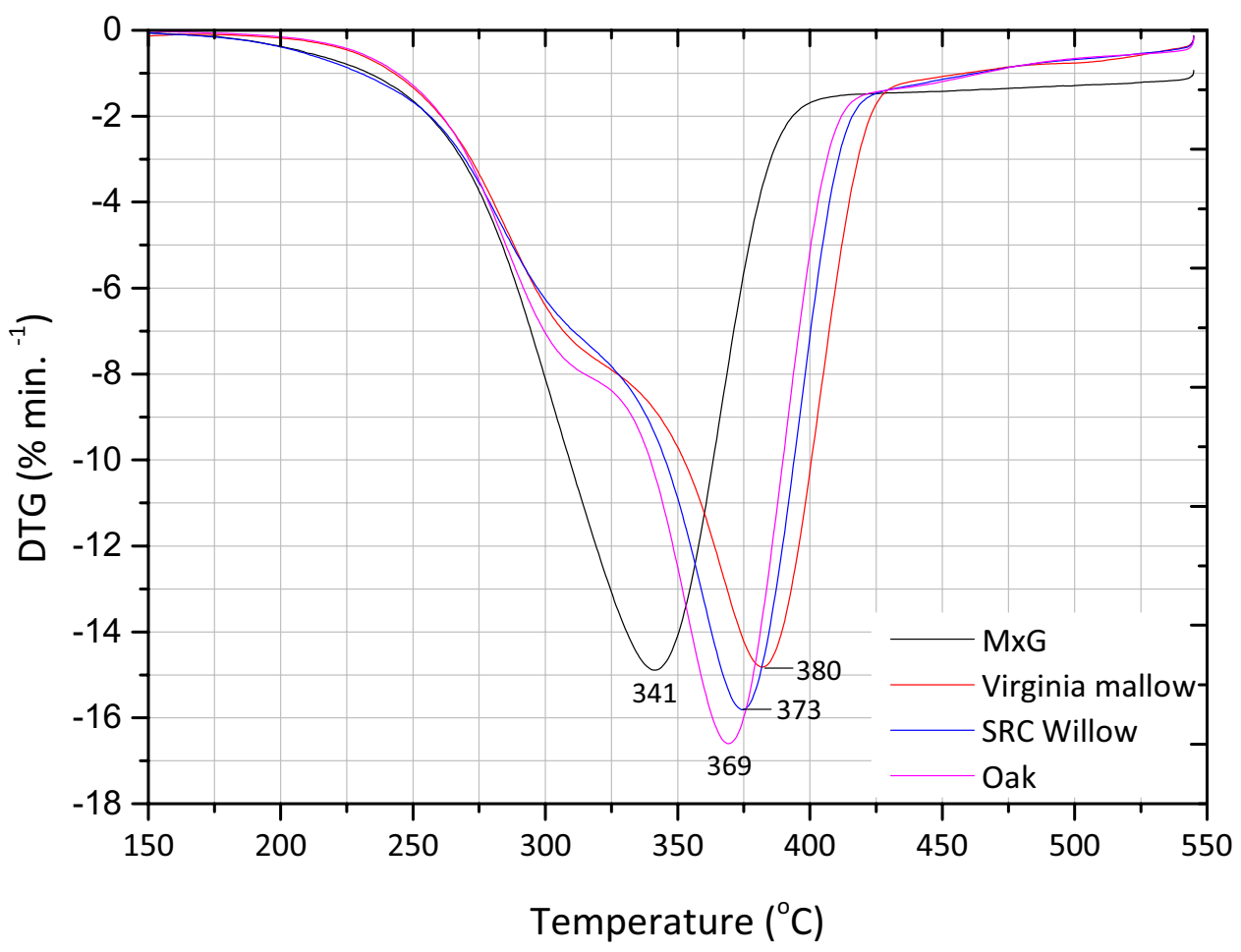

Fig. 3 Differential thermogravimetric combustion profiles

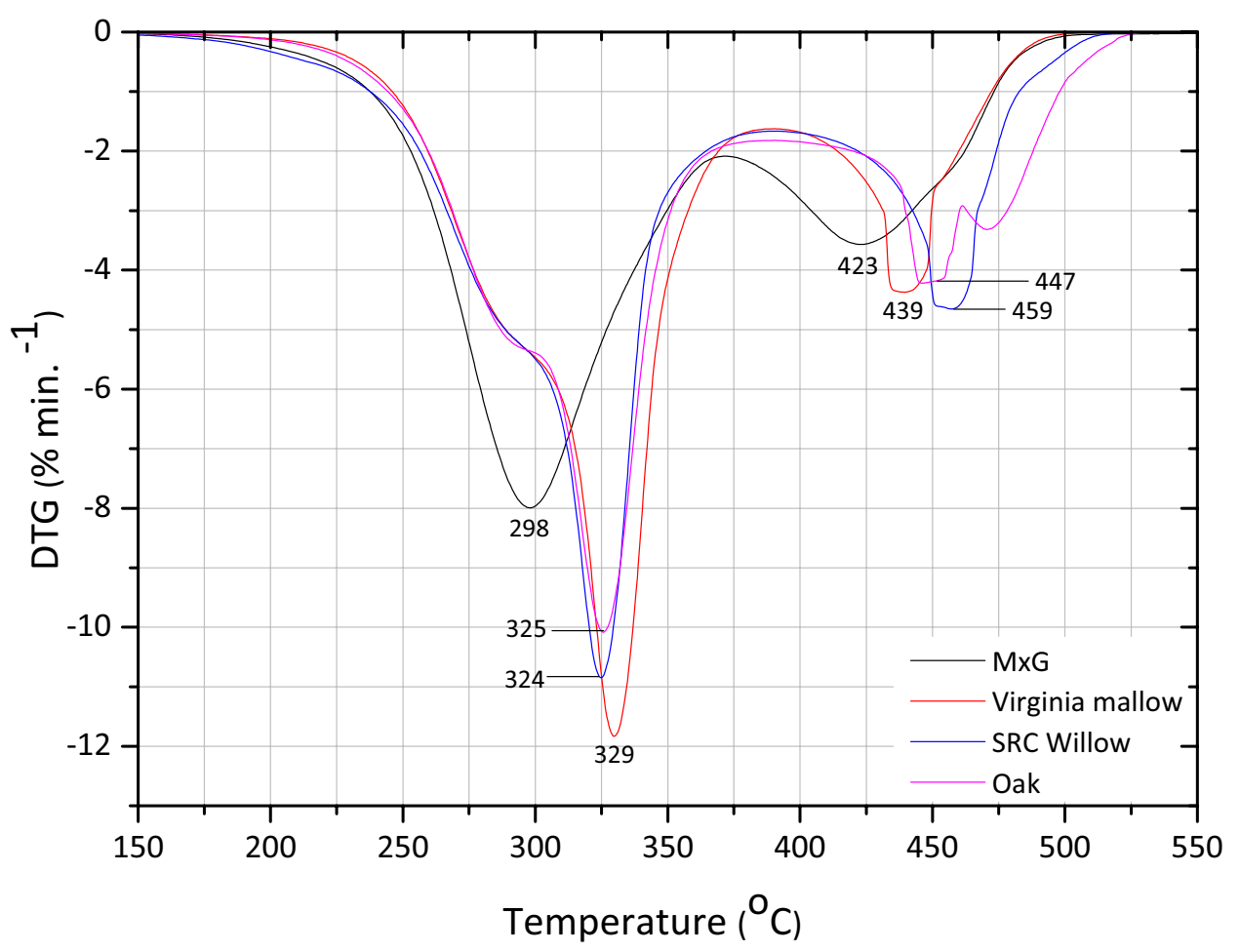

\section{Analytical Pyrolysis (Py-GC-MS)}

Pyrolysis-gas chromatography-mass spectrometry (Py-GC-MS) analysis was applied to study the generation of heavier hydrocarbons produced during pyrolysis of fast pyrolysis feedstocks. Figure 4 show the Py-GC-MS chromatograms for all feedstocks investigated. The key lignin and holocellulose (cellulose and hemicellulose) derived pyrolytic decomposition marker compounds were identified, with the holocellulose fraction comprised the major proportion 

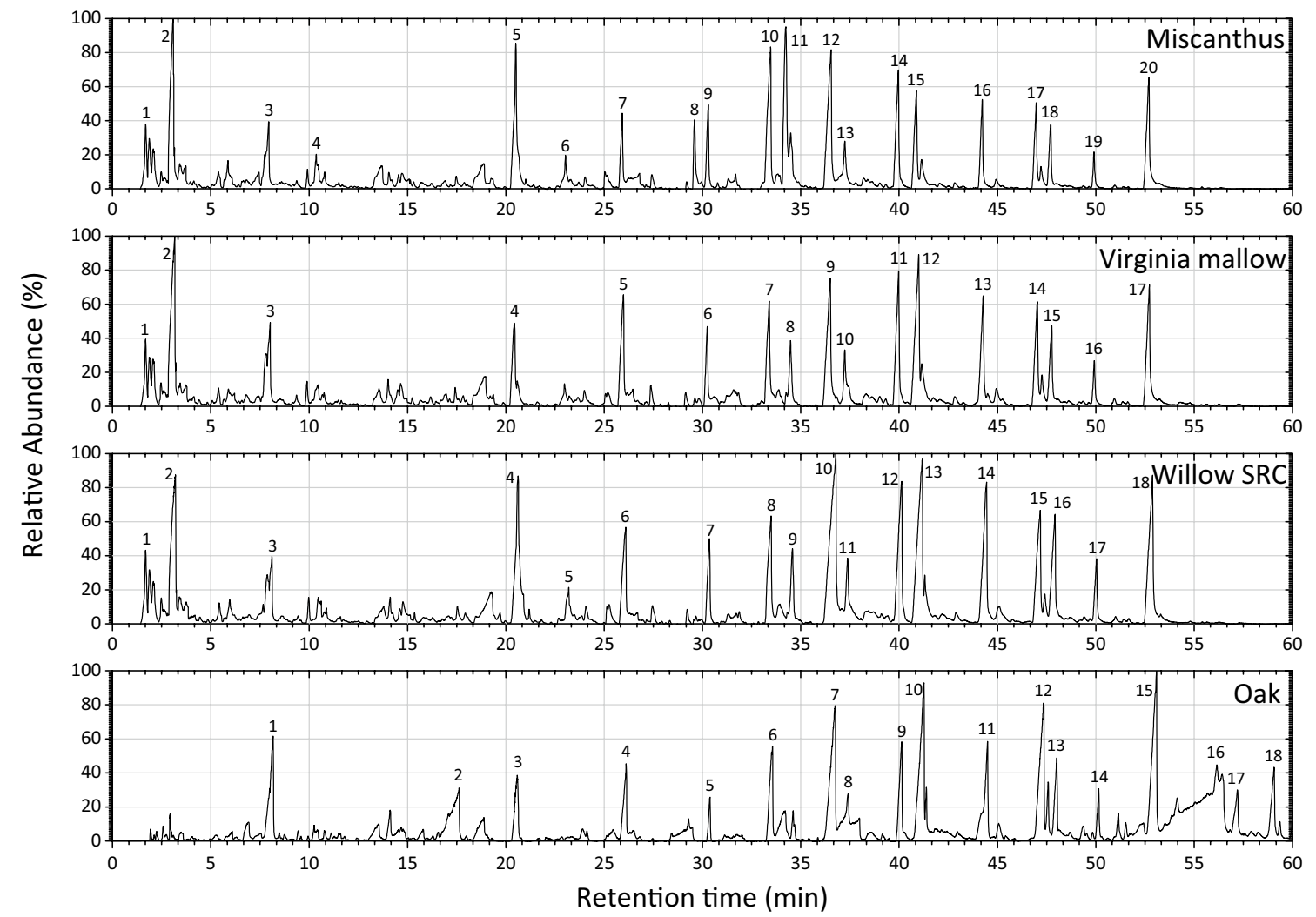

Fig. 4 Py-GC-MS chromatograms for studied feedstocks. Miscanthus (1) 2-methyl-furan, (2) acetic acid, (3) furfural, (4) 2-furanmethanol, (5) 2-methoxy-phenol, (6) 3-methyl-phenol, (7) creosol, (8) 4-ethyl-phenol, (9) 4-ethyl-2-methoxy-phenol, (10) 2-methoxy4-vinylphenol,(11) 2-methyl-benzaldehyde, (12) 2, 6-dimethoxyphenol, (13) trans-isoeugenol, (14) 2-methoxy-4-(1-propenyl)-phenol, (15) 4-methoxy-3-(methoxymethyl)-phenol, (16) 5-tert-butylpyrogallol, (17) 3, 5-dimethoxyaceto-phenone, (18) 2, 6-dimethoxy-4-(2propenyl)-phenol, (19) 2, 6-dimethoxy-4-(2-propenyl)-phenol, (20) 2, 6-dimethoxy-4-(2-propenyl)-phenol. Virginia mallow (1) 2-methylfuran, (2) acetic acid, (3) furfural, (4) 2-methoxy-phenol, (5) creosol, (6) 4-ethyl-2-methoxy-phenol, (7) 2-methoxy-4-vinylphenol,(8) eugenol, (9) 2, 6-dimethoxy-phenol, (10) trans-isoeugenol, (11) 2-methoxy-4-(1-propenyl)-phenol, (12) 4-methoxy-3-(methoxymethyl)-phenol, (13) 5-tert-butylpyrogallol, (14) 3, 5-dimethoxyacetophenone, (15) 2, 6-dimethoxy-4-(2-propenyl)-phenol, (16) 2, 6-dimethoxy4-(2-propenyl)-phenol, (17) 2, 6-dimethoxy-4-(2-propenyl)-phenol.

Table 3 Py-GC-MS compound composition

\begin{tabular}{lcccr}
\hline $\begin{array}{l}\text { Compound } \\
\text { groups }\end{array}$ & Miscanthus & $\begin{array}{l}\text { Virginia mal- } \\
\text { low }\end{array}$ & SRC willow & Oak \\
& Yield (\%) & & & \\
\hline Acids & 6.25 & 5.78 & 4.86 & 0.00 \\
Aldehydes & 6.04 & 0.00 & 0.00 & 0.00 \\
Furans & 5.72 & 5.07 & 4.44 & 3.91 \\
Ketones & 3.08 & 3.47 & 3.57 & 6.82 \\
Phenols & 46.53 & 54.33 & 51.62 & 45.07 \\
Anhydrosugars & 0.00 & 0.00 & 0.00 & 2.58 \\
Unidentified & 32.38 & 40.50 & 35.52 & 41.62 \\
\hline
\end{tabular}

Willow SRC (1) 2-methyl-furan, (2) acetic acid, (3) furfural, (4) 2-methoxy-phenol, (5) 3-methyl-phenol, (6) creosol, (7) 4-ethyl2-methoxy-phenol, (8) 2-methoxy-4-vinylphenol,(9) eugenol, (10) 2, 6-dimethoxy-phenol, (11) trans-isoeugenol, (12) 2-methoxy-4-(1propenyl)-phenol, (13)1, 2, 4-trimethoxybenzene, (14) 5-tert-butylpyrogallol, (15) 3, 5-dimethoxyacetophenone, (16) 2, 6-dimethoxy4-(2-propenyl)-phenol, (17) 2, 6-dimethoxy-4-(2-propenyl)-phenol, (18) 2, 6-dimethoxy-4-(2-propenyl)-phenol. Oak (1) furfural, (2) 2, 3-dimethyl-2-cycloenten-1-one, (3) 2-methoxy-phenol, (4) creosol, (5) 4-ethyl-2-methoxy-phenol, (6) 2-methoxy-4-vinylphenol,(7) 2, 6-dimethoxy-phenol, (8) 2-methoxy-4-(1-propenyl)-phenol, (9) trans-isoeugenol, (10)1, 2, 4-trimethoxybenzene, (11) 5-tert-butylpyrogallol, (12) 3, 5-dimethoxyacetophenone, (13) 2, 6-dimethoxy4-(2-propenyl)-phenol, (14) 2, 6-dimethoxy-4-(2-propenyl)-phenol, (15) 2, 6-dimethoxy-4-(2-propenyl)-phenol, (16) 1,6-anhydro- $\beta$-Dglucopyranose, (17) 1-(4-hydroxy-3, 5-dimethoxyphenyl)-ethanone, (18) Desaspidinol

of the studied biomass. The Py-GC-MS chromatograms are mainly composed of oxygenated organic compounds such as organic acids, aldehydes, furans, ketones and phenols. The Py-GS-MS yields of these compounds are given in Table 3 for comparison. Similar yields of phenols were found for all feedstock (45.07-54.33\%). The significant difference in yields was for the production of organic acids, aldehydes and ketones. Py-GC-MS of oak produced no yield of organic acids and a slightly higher yield of ketones compared to miscanthus, SRC willow and Virginia mallow. Miscanthus was the only feedstock to produce any aldehydes and oak levoglucosan (1,6-anhydro- $\beta$-D-glucopyranose). The difference 
in yields of oxygenated compounds is mainly due to the feedstock composition i.e. yields of cellulose, hemicellulose and lignin. Differences in holocellulose-derived compounds (acetic acid, methyl-furan, furfural and furan-methanol) can be explained not only by variation in biomass composition, but also the portions of alkali metals promoting catalytic

Table 4 Fast pyrolysis mass balances on dry basis (wt \%)

\begin{tabular}{|c|c|c|c|c|}
\hline \multirow[t]{2}{*}{ Products } & \multicolumn{4}{|l|}{ Feedstock } \\
\hline & Miscanthus & $\begin{array}{l}\text { Virginia mal- } \\
\text { low }\end{array}$ & SRC willow & Oak \\
\hline Char & 21.13 & 17.17 & 16.09 & 13.62 \\
\hline Bio-oil & 53.46 & 65.36 & 62.55 & 66.43 \\
\hline Phase & Single & Single & Single & Single \\
\hline Organics & 35.83 & 52.87 & 48.67 & 51.89 \\
\hline Reaction water & 17.64 & 12.49 & 13.88 & 14.53 \\
\hline Gas total & 22.22 & 13.11 & 16.45 & 15.83 \\
\hline $\mathrm{H}_{2}$ & 0.00 & 0.00 & 0.00 & 0.00 \\
\hline $\mathrm{CO}$ & 5.13 & 2.25 & 2.89 & 3.48 \\
\hline $\mathrm{CH}_{4}$ & 0.58 & 0.92 & 0.61 & 1.07 \\
\hline $\mathrm{CO}_{2}$ & 14.56 & 4.48 & 9.21 & 7.21 \\
\hline Ethene & 0.35 & 0.78 & 0.59 & 0.70 \\
\hline Ethane & 0.43 & 0.99 & 0.66 & 0.99 \\
\hline Propene & 0.75 & 2.62 & 1.71 & 1.43 \\
\hline Propane & 0.00 & 0.00 & 0.00 & 0.00 \\
\hline n-Butane & 0.42 & 1.05 & 0.79 & 0.96 \\
\hline $\begin{array}{l}\text { Mass balance } \\
\text { closure }\end{array}$ & 96.81 & 95.64 & 95.10 & 95.88 \\
\hline
\end{tabular}

decomposition of cellulose and its pyrolytic decomposition intermediate-levoglucosan.

The short hold time at the pyrolysis temperature can be a reason for the low overall yields found, resulting in many compounds having a relative abundance below $20 \%$. Longer hold times have been shown to influence the yields of compounds produced [29]. Longer hold times could, therefore, help to reduce the unidentified compound yields, which ranged from 32.38 to $41.62 \%$.

\section{Fast Pyrolysis Processing Experiments}

The fast pyrolysis process conditions and mass balance for the miscanthus, Virginia mallow, short rotation coppice willow and oak are summarised in Tables 1 and 4. Good mass balance closures were achieved for all feedstocks in all runs $(>95 \%)$. Losses in the mass balance are thought to be caused by errors in water content analysis, weight measurement and gas analysis errors caused by heavily diluted pyrolysis gases (content of nitrogen above 95\%). A graphical representation of the data in Table 4 can be found in Fig. 5. This clearly shows the difference in feedstock fast pyrolysis yields. The organic liquid yield was highest for Virginia mallow (52.87 wt \%) while oak had a slightly lower yield (51.89 wt\%). From the preliminary thermogravimetric data presented in Table 2, miscanthus had the lowest volatile content, and Virginia mallow had the highest volatile content, which relates to the actual bio-oil yields (Table 4). Hardwoods have been shown to produce the highest organic liquid yields by fast pyrolysis [30], which highlights the potential of Virginia mallow as an energy feedstock. Char yields are directly related to initial

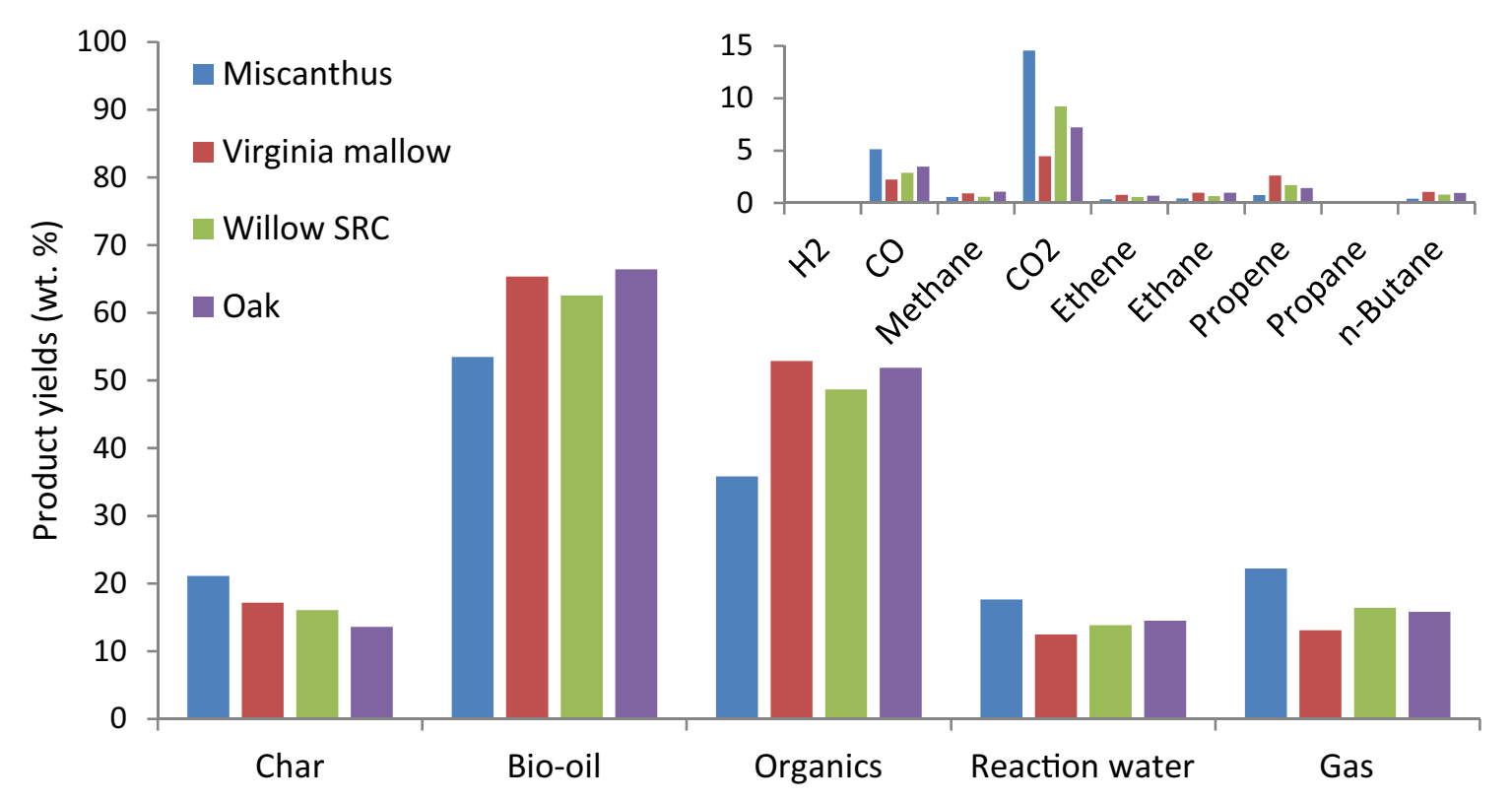

Fig. 5 Mass balance and gas analysis on dry basis for miscanthus, Virginia mallow, SRC willow and oak 
feedstock ash content. Miscanthus had the highest ash content $(2.79 \%$, ASTM) which resulted in the highest yield of char (21.13 wt \%) and oak had the lowest ash content $(0.23 \%$, ASTM) which resulted in the lowest char yield (13.62 wt \%). Higher ash content can lead to catalysed repolymerisation and cross-linking reactions occurring during fast pyrolysis [31], which leads to an increase in char yield. The gas analysis shows that the yields of non-condensable gases such as carbon dioxide and carbon monoxide are highest for miscanthus. This high yield of non-condensable gas can be related to miscanthus having the highest ash content. Virginia mallow has the lowest non-condensable gas yield of all fast pyrolysis feedstocks processed. Further analysis of the composition of the feedstock ash is required, as a significant constituent of ash has significant effects on fast pyrolysis product yields, in particular alkali metals [32-37]. High ash contents (miscanthus-2.79 wt $\%$ and Virginia mallow-2.32 $\mathrm{wt} \%$, Table 2) do not necessarily mean high alkali metal content. A majority of ash can be made up of silica which has no or little effect on fast pyrolysis product yields. Therefore, even though miscanthus and Virginia mallow have similar ash contents, the composition of the ash has greatly varying effects on fast pyrolysis product yields and characteristics as shown by fast pyrolysis mass balances (Table 4).

\section{Product Characterisation}

The properties of the bio-oils produced are shown in Table 5. Miscanthus has the highest bio-oil water content, and Virginia mallow has the lowest bio-oil water content. The water in the bio-oil originates from the initial feedstock water content and dehydration reactions occurring during the fast pyrolysis process [38]. The initial water content of the feedstock shown in Table 1 ranged from 7.02 to 11.60 $\mathrm{wt} \%$. The water content is relative to the initial feedstock moisture. It was concluded by Ibrahim et al. [39] that the water in bio-oil mostly originates from the original moisture in the feedstock. Therefore, it is advantageous to dry
Table 5 Bio-oil and char analysis

\begin{tabular}{|c|c|c|c|c|}
\hline & Miscanthus & Virginia mallow & SRC willow & Oak \\
\hline \multicolumn{5}{|l|}{ Bio-oil properties } \\
\hline Water content $(\mathrm{wt} \%)$ & 39.68 & 13.82 & 19.22 & 18.93 \\
\hline $\mathrm{pH}$ & 3.65 & 3.44 & 3.50 & 2.95 \\
\hline Homogeneity & Single-phase & Single-phase & Single-phase & Single-phase \\
\hline \multicolumn{5}{|c|}{ Elemental composition (wt\% d.b.) } \\
\hline Carbon & 56.40 & 55.40 & 53.59 & 51.86 \\
\hline Hydrogen & 7.89 & 7.15 & 7.66 & 7.4 \\
\hline Nitrogen & 0.26 & 0.09 & 0.37 & 0.1 \\
\hline Sulphur & $\mathrm{n} / \mathrm{d}$ & $\mathrm{n} / \mathrm{d}$ & $\mathrm{n} / \mathrm{d}$ & $\mathrm{n} / \mathrm{d}$ \\
\hline Oxygen $^{a}$ & 35.45 & 37.36 & 38.38 & 40.64 \\
\hline \multicolumn{5}{|c|}{ Heating values $\left(\mathrm{MJ} \mathrm{kg}^{-1}\right)$} \\
\hline HHV (a.r) & 15.27 & 20.60 & 19.19 & 18.34 \\
\hline LHV (a.r) & 13.26 & 18.92 & 17.37 & 16.57 \\
\hline "H:C" atomic ratio & 0.17 & 0.16 & 0.18 & 0.18 \\
\hline "O:C" atomic ratio & 0.63 & 0.67 & 0.72 & 0.78 \\
\hline \multicolumn{5}{|l|}{ Char properties } \\
\hline \multicolumn{5}{|c|}{ Elemental composition (wt\% d.b.) } \\
\hline Carbon & 52.89 & 57.62 & 56.48 & 62.57 \\
\hline Hydrogen & 3.37 & 3.50 & 2.86 & 3.08 \\
\hline Nitrogen & 0.41 & 0.63 & 0.92 & 0.50 \\
\hline Sulphur & $\mathrm{n} / \mathrm{d}$ & $\mathrm{n} / \mathrm{d}$ & $\mathrm{n} / \mathrm{d}$ & $\mathrm{n} / \mathrm{d}$ \\
\hline Oxygen $^{a}$ & 43.34 & 38.25 & 39.75 & 33.85 \\
\hline Ash (wt\% d.b.) & 30.19 & 23.13 & 25.13 & 19.06 \\
\hline \multicolumn{5}{|c|}{ Heating values $\left(\mathrm{MJ} \mathrm{kg}^{-1}\right)$} \\
\hline HHV (d.b.) & 17.31 & 19.79 & 18.43 & 21.56 \\
\hline LHV (d.b.) & 16.57 & 19.02 & 17.81 & 20.89 \\
\hline "H:C" atomic ratio & 0.06 & 0.06 & 0.05 & 0.05 \\
\hline "O:C" atomic ratio & 0.82 & 0.66 & 0.70 & 0.54 \\
\hline
\end{tabular}

d.b. dry basis, a.r. as received (wet basis), $n / d$ not detected

${ }^{\text {a By difference }}$ 
biomass before fast pyrolysis to less than $10 \mathrm{wt} \%$ in order to minimise the water in the final bio-oil product.

The bio-oil water content had a direct effect on the higher heating value as shown by Virginia mallow bio-oil which had the lowest water content $(13.82 \mathrm{wt} \%)$ and the highest heating value $\left(20.60 \mathrm{MJ} \mathrm{kg}^{-1}\right)$. The basic elemental analysis for the bio-oils and chars produced are shown in Table 5. The $\mathrm{H}: \mathrm{C}$ and $\mathrm{O}: \mathrm{C}$ atomic ratios for the feedstocks, bio-oils and chars are shown in Fig. 6. Three main clusters can be seen on the Van Krevelen diagram, each cluster representative of the fast pyrolysis feedstock, bio-oil and char. Fast pyrolysis had a distinct effect on the pyrolysis product O:C and $\mathrm{H}: \mathrm{C}$ atomic ratios. Fast pyrolysis has reduced the biooil and char O:C atomic ratio from $0.88-1.00$ to $0.54-0.82$, therefore producing a more carbonaceous bio-oil and char product. Bio-oil is chemically and thermally unstable due to its high content of reactive oxygen-containing compounds, so by reducing the $\mathrm{O}: \mathrm{C}$ atomic ratio helps to improve the chemical and thermal stability. The char $\mathrm{H}: \mathrm{C}$ was found to be very low $(0.05-0.06)$ when compared to the feedstocks and the bio-oil produced (0.12-0.16). The low $\mathrm{H}: \mathrm{C}$ and O:C atomic ratios in char is typical for increased carbon-carbon bonds [40, 41].

The bio-oil produced from fast pyrolysis for each feedstock was compared by GC-MS, and the resulting chromatograms are presented in Fig. 7. The bio-oils are mainly composed of oxygenated organic compounds such as organic acids, alcohols, aldehydes, ethers, furans, ketones and phenols. The fast pyrolysis bio-oil yields of these compounds are given in Table 6 for comparison. This comparison of compounds identifies that there are similarities between the bio-oils produced from different feedstocks. Virginia mallow and oak bio-oils have similar furan and phenol yields, which have relatively high energy density and are direct replacements for petroleum fuels or as fuel additives [42-44].

The fast pyrolysis chars were analysed by thermogravimetric analysis, and this is shown in Fig. 8. The maximum thermal degradation occurred between 375 and $550^{\circ} \mathrm{C}$. The ash content within the char is shown in Table 5. The char ash content is typically higher than the initial feedstock because the non-volatile inorganics will mainly remain within the char. Silica sand can also be entrained from the reactor bed to be collected in the char pot, resulting in a higher than expected char ash content. Oak char had the highest higher heating value of $21.56 \mathrm{MJ} \mathrm{kg}^{-1}$, and this is due to having the highest carbon content and lowest ash content found in the char.

\section{Conclusions}

Analytical and laboratory-scale fast pyrolysis has been used to compare the potential of Virginia mallow as an energy feedstock with other high yielding perennial grasses and hardwoods. The analytical analysis found that oak had the highest calorific value due to having the highest carbon content and lowest ash content. Virginia mallow had a slightly lower calorific value due to an increased ash content compared to oak. Py-GC-MS analysis identified that similar yields of phenols were found for all feedstocks. The difference in yields was identified for the production of organic acids, aldehydes and ketones. These differences can be caused by the varying composition of the feedstocks in terms of cellulose, hemicellulose and lignin content. The short hold time at the pyrolysis temperature can be a reason for
Fig. 6 Van Krevelen diagram$\mathrm{H}: \mathrm{C}$ and $\mathrm{O}: \mathrm{C}$ atomic ratios of fast pyrolysis feedstocks, fast pyrolysis bio-oil and fast pyrolysis char. Biomass feedstock-miscanthus 1; Virginia mallow 2; SRC willow 3; oak 4); (Bio-oil-miscanthus 5; Virginia mallow 6; SRC willow 7; oak 8); (Char-miscanthus 9; Virginia mallow 10; SRC willow 11; oak 12)

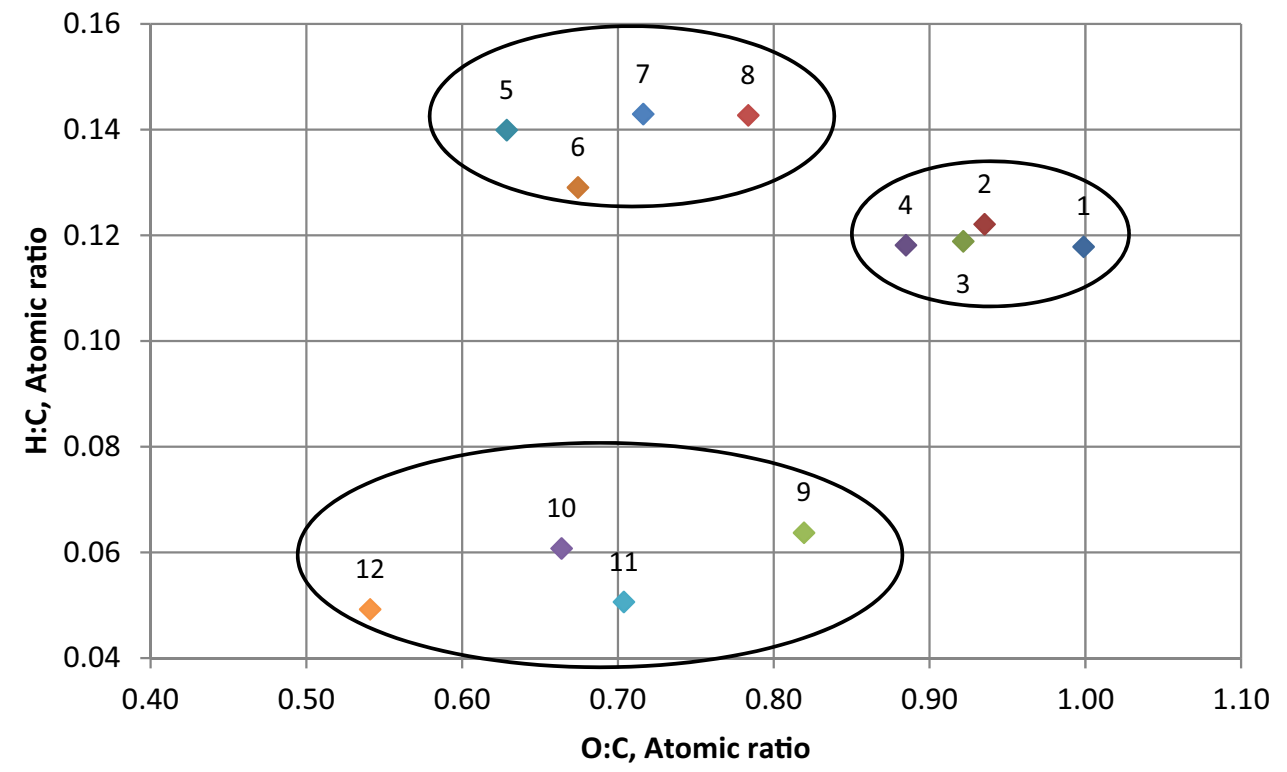



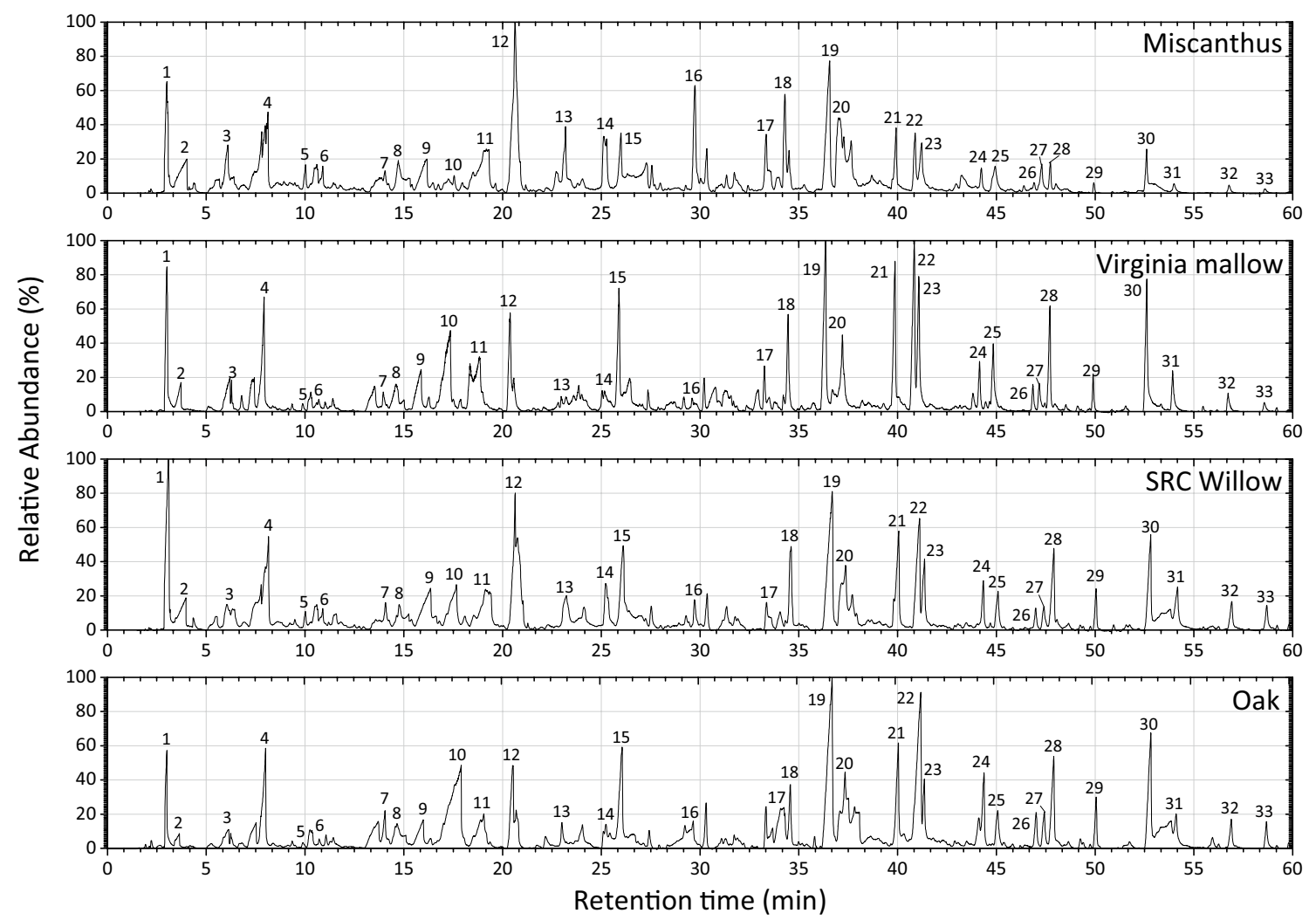

Fig. 7 Bio-oil chromatograms for miscanthus, Virginia mallow, SRC willow and oak. Peak assignments: (1) acetic acid, (2) methyl ester acetic acid, (3) 1-hydroxy-2-butanone, (4) furfural, (5) 2-methyl 2-cyclopenten-1-one, (6) 1-(2-furanyl)-ethanone, (7) 5-methyl, 2-furancarboxaldehyde, (8) 3-hepten-1-ol, (9) 2(5H)-furanone, (10) 2, 3-dimethyl-2-cyclopenten-1-one, (11) 3-methyl, 1, 2-cyclopentanedione, (12) 2-methoxy, phenol, (13) 2-methyl, phenol, (14) p-cresol, (15) creosol, (16) 4-ethyl, phenol, (17) 2-methoxy-4-vinylphenol, (18) 2, 3-dihydro-benzofuran, (19) 2, 6-dimethoxy-phenol,

Table 6 Fast pyrolysis bio-oil compound composition from $300 \mathrm{~g} \mathrm{~h}^{-1}$ fast pyrolysis unit

\begin{tabular}{lclcr}
\hline $\begin{array}{l}\text { Compound } \\
\text { groups }\end{array}$ & Miscanthus & $\begin{array}{l}\text { Virginia mal- } \\
\text { low }\end{array}$ & SRC willow & Oak \\
& Yield (\%) & & & \\
\hline Acids & 5.99 & 6.44 & 8.04 & 4.46 \\
Alcohols & 1.28 & 0.94 & 0.89 & 0.83 \\
Aldehydes & 0.31 & 1.47 & 1.09 & 0.95 \\
Ethers & 0.29 & 0.98 & 0.89 & 1.40 \\
Furans & 6.14 & 6.44 & 6.72 & 5.90 \\
Ketones & 6.53 & 9.25 & 5.62 & 7.17 \\
Phenols & 45.37 & 50.92 & 45.96 & 50.65 \\
Unidentified & 34.09 & 23.57 & 30.79 & 28.63 \\
\hline
\end{tabular}

the low overall yields found, resulting in many compounds having a relative abundance below $20 \%$.
(20) catechol, (21) 2-methoxy-4-(1-propenyl), phenol, (22) 4-methoxy-3-(methoxymethyl)-phenol, (23) vanillin, (24) 5-tert-butylpyrogallol, (25) apocynin, (26) 3-tert-butyl-4-hydroxyanisole, (27) 1-(4-hydroxy-3-methoxyphenyl)-2-propanone, (28) 2, 6-dimethoxy4-(2-proenyl)-phenol, (29) 2, 6-dimethoxy-4-(2-proenyl)-phenol, (30) 2, 6-dimethoxy-4-(2-proenyl)-phenol, (31) 4-hydroxy, 3, 5-dimethoxy benzaldehyde, (32) 1-(4-3, 5-dimethoxyphenol)-ethanone, (33) desaspidinol

Laboratory scale fast pyrolysis processing identified that Virginia mallow had the highest organic liquid yield (52.87 wt $\%$ ) while oak had a slightly lower yield (51.89 wt \%). Miscanthus had the lowest organic liquid yield (35.83 wt \%). Water content within the bio-oil is highest for miscanthus (39.68 wt\%) and lowest for Virginia mallow (13.82 wt\%). The hardwoods have a slightly higher water content within the bio-oil compared to Virginia mallow (18.93-19.22 wt\%). Feedstock ash content has a direct effect on fast pyrolysis product yields, in particular the alkali metal content. Miscanthus and Virginia mallow both have high ash contents (2.79 wt\% and $2.32 \mathrm{wt} \%$ respectively) but drastically different fast pyrolysis yields. Virginia mallow has similar fast pyrolysis yields to oak which has a lower ash content $(0.23$ $\mathrm{wt} \%$ ), emphasising that the composition of ash is critical in fast pyrolysis processing and that high liquid yields can still be achieved with a high ash content feedstock. Virginia mallow and oak bio-oils have a similar composition with regards to furans and phenolics which are direct replacements for 
Fig. 8 Differential thermogravimetric combustion profiles of fast pyrolysis chars

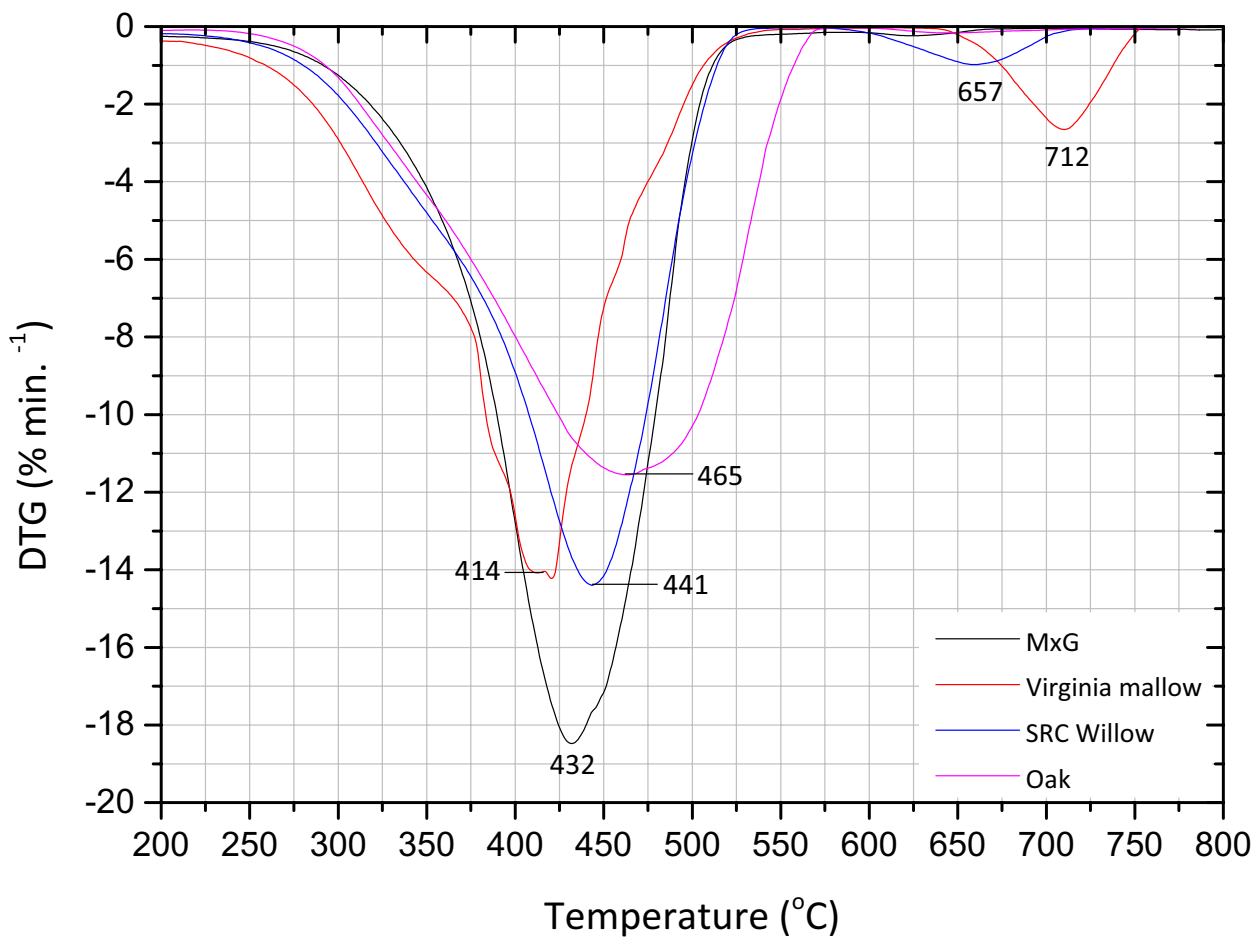

petroleum fuels or as fuel additives highlighting the relevance of Virginia mallow as a potential energy feedstock.

In summary, Virginia mallow generates similar homogeneous bio-oil liquid yields compared to the hardwood feedstocks, but Virginia mallow has far higher productivity (9 to $\left.20 \mathrm{t} \mathrm{ha}^{-1} \mathrm{DM}\right)$. The high bio-oil and char heating value and low water content found in Virginia mallow, as well as the potential for production of petroleum fuel replacements, fuel additives or upgrading to value-added chemicals, make this crop an attractive energy feedstock for fast pyrolysis processing.

Acknowledgements Support through the EPSRC SUPERGEN Challenge project Development of fast pyrolysis based advanced biofuel technologies for biofuels No. EP/K036548/1 is particularly acknowledged. The authors wish to thank the Biofuels Research Infrastructure for Sharing Knowledge (BRISK) for funding Malwina Snieg to undertake this research.

Open Access This article is licensed under a Creative Commons Attribution 4.0 International License, which permits use, sharing, adaptation, distribution and reproduction in any medium or format, as long as you give appropriate credit to the original author(s) and the source, provide a link to the Creative Commons licence, and indicate if changes were made. The images or other third party material in this article are included in the article's Creative Commons licence, unless indicated otherwise in a credit line to the material. If material is not included in the article's Creative Commons licence and your intended use is not permitted by statutory regulation or exceeds the permitted use, you will need to obtain permission directly from the copyright holder. To view a copy of this licence, visit http://creativecommons.org/licenses/by/4.0/.

\section{References}

1. Haines, A., et al.: Climate change and human health: impacts, vulnerability and public health. Public Health 120(7), 585-596 (2006)

2. Sathre, R.: Comparing the heat of combustion of fossil fuels to the heat accumulated by their lifecycle greenhouse gases. Fuel 115, 674-677 (2014)

3. Bridgwater, A.V.: Review of fast pyrolysis of biomass and product upgrading. Biomass Bioenergy 38, 68-94 (2012)

4. Rickett, H.W.: New Field Book of American Wild Flowers. G.P. Putnam's, New York (1963)

5. Kujawski, J., Woolston, D., Englert, J.: Propagation of Virginia Mallow from seeds, rhizomes (Virginia). Restor. Manag. Notes 15(2), 193-194 (1997)

6. Šiaudinis, G., et al.: The assessment of Virginia mallow (Sida hermaphrodita Rusby) and cup plant (Silphium perfoliatum L.) productivity, physico-mechanical properties and energy expenses. Energy 93, 606-612 (2015)

7. Nahm, M., Morhart, C.: Virginia mallow (Sida hermaphrodita (L.) Rusby) as perennial multipurpose crop: biomass yields, energetic valorization, utilization potentials, and management perspectives. GCB Bioenergy 10(6), 393-404 (2018)

8. Krzyżaniak, M., Stolarski, M.J., Warmiński, K.: Life cycle assessment of Virginia mallow production with different fertilisation options. J. Clean. Prod. 177, 824-836 (2018)

9. Borkowska, H., Molas, R., Kupczyk, A.: Virginia fanpetals (Sida hermaphrodita Rusby) cultivated on light soil; height of yield and biomass productivity. Pol. J. Environ. Stud. 18(4), 563-568 (2009)

10. Borkowska, H., Molas, R.: Yield comparison of four lignocellulosic perennial energy crop species. Biomass Bioenergy 51, 145-153 (2013) 
11. Lewandowski, I., et al.: The development and current status of perennial rhizomatous grasses as energy crops in the US and Europe. Biomass Bioenergy 25(4), 335-361 (2003)

12. Kryževičienè, A., Žaltauskas, A., Jasinskas, A.: Cultivation and utilization of the perennial grasses as biofuel. Žemès ūkio Mokslai 1, 40-49 (2005)

13. Borkowska, H., Wardzinska, K.: Some effects of Sida hermaphrodita $\mathrm{R}$. cultivation on sewage sludge. Pol. J. Environ. Stud. 12(1), 119-122 (2003)

14. Krasuska, E., Rosenqvist, H.: Economics of energy crops in Poland today and in the future. Biomass Bioenergy 38, 23-33 (2012)

15. Borkowska, H., Molas, R.: Two extremely different crops, Salix and Sida, as sources of renewable bioenergy. Biomass Bioenergy 36, 234-240 (2012)

16. ASTM International: International Standard Test Method for Compositional Analysis by Thermogravimetry. ASTM International, West Conshohocken (2003)

17. ASTM International: Standard Test Method for Ash in Biomass. ASTM International, West Conshohocken (2007)

18. ASTM International: Standard Test Method for Chemical Analysis of Wood Charcoal. ASTM International, West Conshohocken (2007)

19. Channiwala, S., Parikh, P.: A unified correlation for estimating HHV of solid, liquid and gaseous fuels. Fuel 81(8), 1051-1063 (2002)

20. Faix, O., Meier, D., Fortmann, I.: Thermal degradation products of wood. Holz als Roh- und Werkstoff 48(7-8), 281-285 (1990)

21. Faix, O., et al.: Thermal degradation products of wood. Holz als Roh- und Werkstoff 49(5), 213-219 (1991)

22. Chen, B.-C., Lai, H.-Y., Juang, K.-W.: Model evaluation of plant metal content and biomass yield for the phytoextraction of heavy metals by switchgrass. Ecotoxicol. Environ. Saf. 80, 393-400 (2012)

23. Greenhalf, C., et al.: A comparative study of straw, perennial grasses and hardwoods in terms of fast pyrolysis products. Fuel 108, 216-230 (2013)

24. Nowakowski, D.J., et al.: Potassium catalysis in the pyrolysis behaviour of short rotation willow coppice. Fuel 86(15), 23892402 (2007)

25. Yang, H., et al.: Characteristics of hemicellulose, cellulose and lignin pyrolysis. Fuel 86(12), 1781-1788 (2007)

26. Kan, T., Strezov, V., Evans, T.J.: Lignocellulosic biomass pyrolysis: a review of product properties and effects of pyrolysis parameters. Renew. Sustain. Energy Rev. 57, 1126-1140 (2016)

27. Ghetti, P., Ricca, L., Angelini, L.: Thermal analysis of biomass and corresponding pyrolysis products. Fuel 75(5), 565-573 (1996)

28. Burhenne, L., et al.: The effect of the biomass components lignin, cellulose and hemicellulose on TGA and fixed bed pyrolysis. J. Anal. Appl. Pyrol. 101, 177-184 (2013)

29. Greenhalf, C.E., et al.: Sequential pyrolysis of willow SRC at low and high heating rates-implications for selective pyrolysis. Fuel 93, 692-702 (2012)
30. Demirbas, A.: The influence of temperature on the yields of compounds existing in bio-oils obtained from biomass samples via pyrolysis. Fuel Process. Technol. 88(6), 591-597 (2007)

31. Trubetskaya, A., Timko, M.T., Umeki, K.: Prediction of fast pyrolysis products yields using lignocellulosic compounds and ash contents. Appl. Energy 257, 113897 (2020)

32. Lin, X., et al.: Effects of alkali and alkaline earth metals on the co-pyrolysis of cellulose and high density polyethylene using TGA and Py-GC/MS. Fuel Process. Technol. 191, 71-78 (2019)

33. Mohammed, I.Y., et al.: Effects of pretreatments of napier grass with deionized water, sulfuric acid and sodium hydroxide on pyrolysis oil characteristics. Waste Biomass Valoriz. 8(3), 755773 (2017)

34. Carpenter, D., et al.: Biomass feedstocks for renewable fuel production: a review of the impacts of feedstock and pretreatment on the yield and product distribution of fast pyrolysis bio-oils and vapors. Green Chem. 16(2), 384-406 (2014)

35. Arora, J.S., Chew, J.W., Mushrif, S.H.: Influence of alkali and alkaline-Earth metals on the cleavage of glycosidic bond in biomass pyrolysis: a DFT study using cellobiose as a model compound. J. Phys. Chem. A 122(38), 7646-7658 (2018)

36. Klinger, J.L., et al.: Effect of biomass type, heating rate, and sample size on microwave-enhanced fast pyrolysis product yields and qualities. Appl. Energy 228, 535-545 (2018)

37. Oudenhoven, S.R.G., Westerhof, R.J.M., Kersten, S.R.A.: Fast pyrolysis of organic acid leached wood, straw, hay and bagasse: improved oil and sugar yields. J. Anal. Appl. Pyrol. 116, 253-262 (2015)

38. Balat, M.: Mechanisms of thermochemical biomass conversion processes. Part 1: reactions of pyrolysis. Energy Sources Part A 30(7), 620-635 (2008)

39. Ibrahim, N. et al.: Influence of reaction temperature and water content on wheat straw pyrolysis. Int. J. Chem. Mol. Nucl. Mater. Metall. Eng. 6(10) (2012)

40. McKendry, P.: Energy production from biomass (part 1): overview of biomass. Bioresour. Technol. 83(1), 37-46 (2002)

41. Xiao, X., Chen, Z., Chen, B.: H/C atomic ratio as a smart linkage between pyrolytic temperatures, aromatic clusters and sorption properties of biochars derived from diverse precursory materials. Sci. Rep. 6(1), 22644 (2016)

42. Wang, W., et al.: Catalytic fast pyrolysis of cellulose for increasing contents of furans and aromatics in biofuel production. J. Anal. Appl. Pyrol. 131, 93-100 (2018)

43. Lu, Q., et al.: Catalytic upgrading of biomass fast pyrolysis vapors with titania and zirconia/titania based catalysts. Fuel 89(8), 2096$2103(2010)$

44. Dong, C.-Q., et al.: Characteristics and mechanism study of analytical fast pyrolysis of poplar wood. Energy Convers. Manag. 57, 49-59 (2012)

Publisher's Note Springer Nature remains neutral with regard to jurisdictional claims in published maps and institutional affiliations. 